\title{
CRITICAL ANALYSIS OF THE ZIHĀR CONCEPT IN THE QUR'AN AND ITS CONTEXTUALIZATION IN THE CONTEMPORARY ERA
}

\begin{abstract}
Asrizal Saiin
STAIN Sultan Abdurrahman Kepulauan Riau e-mail: asrizal@stainkepri.ac.id

\begin{tabular}{|l|l|l|}
\hline Submit: 27-02-2021 & Direvisi: 29-04-2021 & Dipublish: 21-06-2021 \\
\hline
\end{tabular}

Abstract: Penulisan artikel ini bertujuan untuk mengetahui konsep zihär yang sudah ada sebelum Islam datang. Kemudian ingin mengetahui bagaimana al-Qur'an memperbaiki terbadap konsep zihār tersebut. Setelah al-Qur'an memberikan petunjuk terkait konsep zibär yang sebenarnya, kemudian dikontekstualisasikan pada zaman sekarang. Metode penelitian yang digunakan adalah penelitian kepustakaan, penulisannya bersifat kualitatif dengan perspektif ke dalam dan interpretatif. Dari penelitian yang dilakukan, dapat dipahami bahwa penjelasan tentang zihär dipaparkan secara jelas di dalam al-Qur'an surat Al-Mujadalah ayat 1 sampai 4. Zihär adalah ucapan seorang suami kepada isterinya bahwa punggungnya sama dengan punggung ibunya. Asbäbun Nuzūl ayat ini adalah karena Khaulah binti Tsa'labah telah dizibär oleh suaminya yang bernama 'Aus bin Tṡāmit. Kemudian Khaulah melaporkannya kepada Nabi Mubammad. Nabi menjawab babwa suaminya sudah haram menggauli Khaulah untuk selama-lamanya. Kemudian ayat ini turun untuk membenarkan hukum bagi orang yang menzihär isterinya. Adapun zihär yang sering terjadi pada masa kontemporer sekarang ini sebenarnya tidak dilakukan sebagai bentuk ucapan suami untuk menyamakan istrinya dengan mahramnya, akan tetapi pada dasarnya tidak ada unsur kesengajaan untuk melakukan ziłhär, karena ucapan yang dilakukan suami yaitu perumpamaan atau penyamaan untuk menyatakan keindaban, kecantikan dan lain sebagainya, bukan untuk menghina atau menyamakan isterinya dengan mabramnya.
\end{abstract}

Kata kunci: Zihār, al-Qur'an, Kontemporer.

\section{INTRODUCTION}

$\boldsymbol{E}_{\text {veryone agrees that the al-Qur'an and }}$ Hadith are the main sources for practicing Islamic law. The two sources are more briefly known as dalil nașh qațh'i. Dalil nașh qath' $i$ is divided into two, namely Qațh'i Wurūd and Qațh'i Dalälah, what is meant here is Qath'i Dalälah. Islamic law at the time of its birth flowed dynamically-responsively and flexibly to the problems at hand (Rahman, 1994: 1826). Starting at the time of the Prophet, all problems could be asked directly to the Prophet and immediately got a solution. However, not today, our distance from the Messenger of Allah is very far away, and various kinds of opinions and views are always debated. Although there is a clear source of texts (al-Qur'an and hadith), there are often differences because the understanding of the texts is not the same.

As a clear source of nashh, the Qur'an and hadith also talk about family harmony. Family harmony is formed by establishing communication. The Prophet exemplified this by joking with his wife and praising her with pleasant words. Therefore, the form of jokes and praise from husband to wife is something that can strengthen a marriage. Even a house will feel empty without joking with the family, especially for the wife in order to maintain the continuity of household life (Abud, 1995: 17). 
If we pay close attention to the forms of jokes and praise made by the Prophet Muhammad to his wife, it is something that can strengthen a marriage. It can be seen that zihār is one part of jokes that can affect relationships in marriage.

So this is very important to discuss in order to avoid unwanted actions. The reason is, this zihar can happen in the daily life of a married couple. To avoid this, the concept of zihar is explained contextually for the present, so that there is no prohibition on the relationship between husband and wife due to the occurrence of zihar which is done indirectly.

From the background that has been explained, it can be formulated how zihàr is in the view of the Qur'an and how it is contextualized in today's contemporary era. In this case, so that the discussion is more focused, it is limited to the meaning of zihār according to the commentators, the interpretation of the verses that discuss zihār, the concept of zihār in the Qur'an and their contextualization.

\section{RESEARCH METHODS}

The research method used in writing scientific papers is literature research (Chozin, 1997: 66), the writing is qualitative, namely a naturalistic or natural inquiry or research method, inward and interpretative perspective (Moleong: 2002: 2). Naturalistic inquiry is a question that arises from the writer regarding the problem being researched. The inward perspective is a rule for finding specific conclusions originally derived from general discussion. Meanwhile, interpretive is the translation or interpretation carried out by the author in interpreting the meaning of a sentence, verse or statement.

\section{DEFINITION OF ZIHĀR}

According to language, the word zihàr is taken from Arabic, namely the word ظhich means 'back'. This is because the Jews likened the wife who is being seduced as a ridden vehicle, so they forbade intercourse with a wife from behind because it could result in the birth of a disabled child (Admisi, 1984: 255). In Islamic law, zihār is used for all members of the human body as Qiyās (analogy) from the word zihār itself (Ghofur, 2001: 379).

Zihār in the term is the utterance of a mukallaf (mature and intelligent person) to his wife that she is the same as his mother. According to Quraish Shihab in his interpretation, it is not only equating his wife with his mother, but also other women who are forbidden to marry, whether due to blood relations, marriage, breastfeeding or other reasons. The words are like the lafadz, "Your back is like my sister's back". The scholars agree that zihär only equates a wife with a mother, as stated in the Qur'an and the Hadith of the Prophet Peace be upon him. So that equating a wife to a woman who is mahram even if only for an honor or an expression of affection for other than the mother has not been said as zihār. However, this act was hated by the Prophet Peace be upon him (Shihab, 2002: 475).

According to history, in the past, the inhabitants of Medina (the zihār sayers) mingled with Jews, where they (the Jews) forbade intercourse with their wives from behind, because they could give birth to 
disabled children. The word 'back' is meant to emphasize the prohibition of having sex with a wife from behind. Therefore, zihär here is the influence of the Jewish belief (Shihab, 2002: 475). The utterance of zihâr in the era of ignorance was used by husbands who intended to forbid intercourse with the wife and it resulted in the wife being haram for the husband and other men forever (Hasan, 1984: 8).

\section{NASH'S EXPLANATION OF ZIHĀR}

The explanation of zihār is given clearly in Nash (al-Qur'an and Hadith). The discussion about zihär in the Qur'an is mentioned in Surah al-Mujādalah verses 1-4. Ahmad Mustafa al-Maraghi in his commentary book, Tafsir al-Maraghi, interprets the word al-Mujādalah with the woman who filed a lawsuit (al-Maraghi, 1993: 337). Surah al-Mujādilah or AlMujādalah according to the majority of scholars, most of the verses consisting of 22 verses are Makkiyah. Al-Qurthubi in his commentary states that there are ten of verses at the beginning of this surah that are madaniyah, while the rest revealed before the Prophet immigrated to Medina. Another narration says that it excludes only the seventh verse.

Allah explains this in the Qur'an Surah al-Mujādalah paragraph 1 :



Means: "Allah has heard of women who filed a lawsuit to you about her husband, and complained (as) to Allah. And Allah heard the answers between you two. Allah is Allhearing, All-seeing".
From the Khaulah complaint, not long after al-Qur'an has answered with respect about what happened. Allah has accepted Khaulah's complaint who complained to the Messenger of Allah about her husband making Khaulah sad and restless, and conveyed this matter to Allah, and Allah Knows best the condition of His servant.

Then Allah answered Khaulah's problem in order to get rid of sadness, anxiety, distress, relieves the narrowness, calm his eyes, wet his throat and return his children to Khaulah's lap, namely children who become sad and because the children also khaula sued his case against the Prophet Peace be upon him (al-Maraghi, 1993: 6).

From this complaint, Allah explained in detail about the clarity of zihàr or actions that 'Aus bin Tsāmit had done to his wife. Allah greatly threatens those who perform zihār on their wives. Therefore, Allah revealed the verse 2 of surah al-Mujādalah:

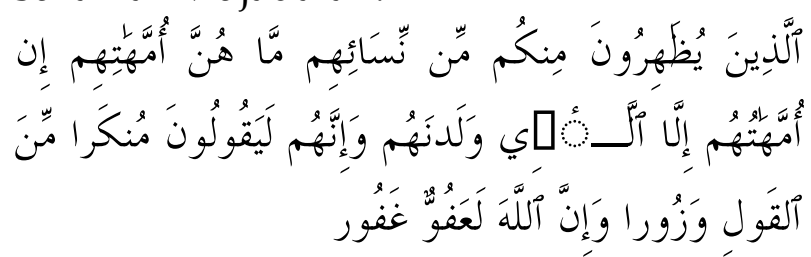

Means: "Those who see wife in you (presuming his wife as his mother, but) none were their wives their mother. Their mothers were none other than the women who gave birth to them, and behold, they do utter a word of disbelief and a lie, and Allah is Most Forgiving, Most Forgiving".

From the above verse, Allah explains that husbands who abuse their wives are despicable (munkar), because they commit lies or sayings that they do, that is, they do not want their wives to be married to other men, but they also don't like their wives or because the wife is no longer 
attractive to the husband, so the husband said something wrong.

Surat al-Mujādalah verse 2 is revealed to explain that zihàr in Islam is no longer a divorce that a husband is haram on his wife forever and without any reconciliation, as was done in the days of Jahiliyah. Therefore, the husband may withdraw his words by paying kaffarat or the law for the actions he has committed. Legal origin, zihar is the act of wrongdoing made by a husband to his wife because the word is a lie. However, Allah will forgive his actions, because Allah is the Most Forgiving and forgives the sins of His servants who are sincere and do not do these deeds again.

People from who fell zihàr to their wives, so that one of them said to his wife, "You are haram to me, just as my mother is haram to $m e^{\prime \prime}$. That means they made mistakes.

Then Allah describes the form of their mistake in Surah al-Mujādalah verse 2, namely:

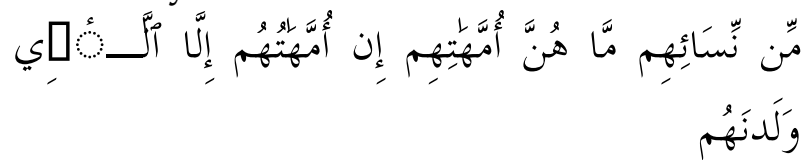

Means: "Their wives were not their mothers the truth, then how do them make wives -their wives as their mothers. Their mothers are the ones who gave birth to them".

The point is that it is not proper to equate these wives with their husband's mothers. Then Allah explained further and reminded them of the bad deeds. The word of Allah swt:

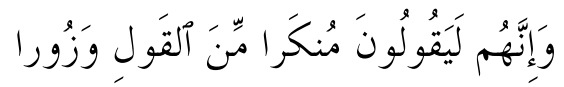

Means: "Indeed, they truly pronounce a word is wrong and a lie"
In the Tafsir Ibn Kathir, explained that indeed they truly pronounce a word is wrong that are prohibited in Islam, are unreasonable and not in accordance with good habits. How can a wife who is loved and loves, between her and her husband, love and care for each other and have a relationship that mother and sister do not have, be likened to a mother who has a relationship of honor, love, majesty and greatness with her child? In addition, the husband is the leader for his wife. Husbands have the right to educate their wives when their wives deviate, and leave them in bed when they cheat. Such rights are not given to a child in association with his mother. Thus, the likeness of the wife to the husband's mother is a lie and a big sin.

In verses 3 and 4, it explains that zihār also has consequences or punishments for someone who does zihār. Allah says in His word:

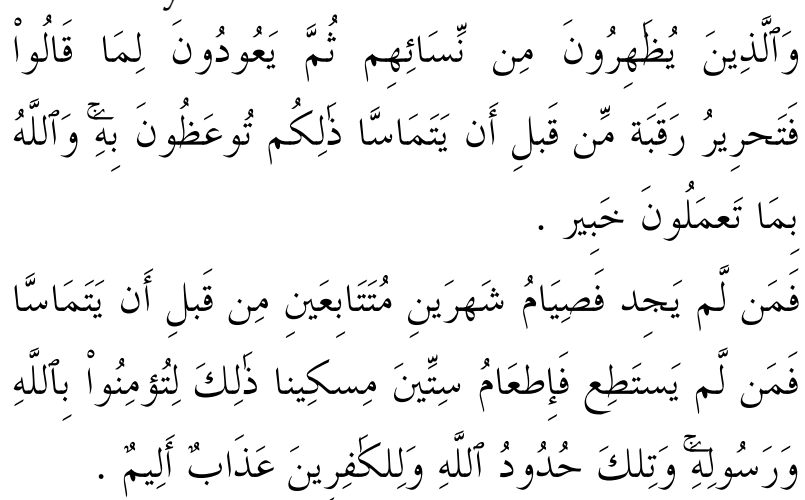

Means: "People who take care of their wives, then they want to take back what they said, then (it is obligatory) to free a slave before the two husband and wife mix. This is what was taught to you, and Allah knows best what you are doing. Whoever does not get (slave), then (obliged to him) fast for two consecutive months before the two mix. Then whoever is not in power (obliged over him) to feed sixty poor people. This is so that you may have faith in Allah and His Messenger, and these are the 
laws of Allah, and for the unbelievers there is a very painful torment.

In verses 3 and 4 are the continuation verses of the explanation zihār of the first and second verses, in which the two verses explain the reason for the fall of the verse which tells of a wife's complaint to the Prophet Muhammad because she had been zihā $r$ by her husband (Shihab, 2010: 473).

Apart from being explained in the alQur'an, it is also explained in the Hadith of the Prophet Muhammad. In the hadith narrated by an-Nasā'i, that the Messenger of Allah explained the story of Khaulah bint Tśa'labah whose hadith text reads as follows:

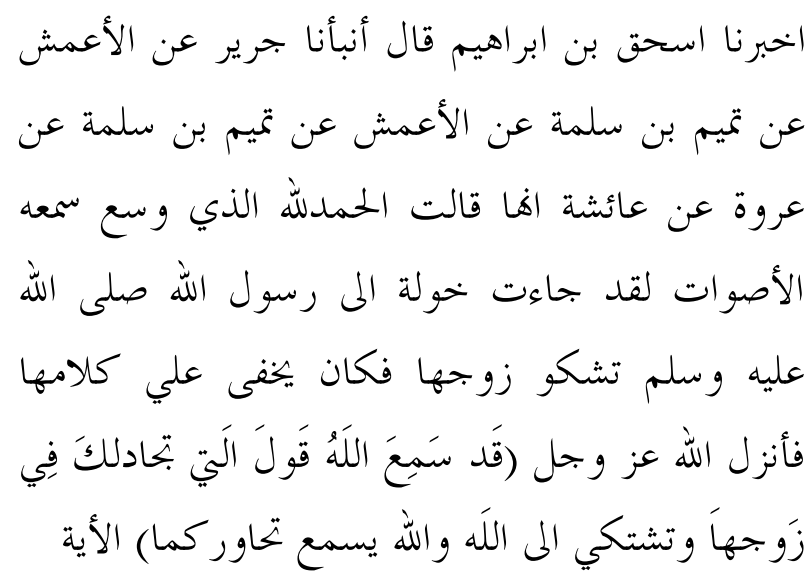

Means: Aisha RA tells that Allah is All Listening to voices. Once upon a time, a woman came complaining to Rasulullah, when I was at the edge of the house listening to the woman's conversation. However, not all I listen to, there are some faint for me. The woman complained about her husband's (who asked for her). He said, 'O Messenger of Allah, my husband has tested my children, even though my stomach has given birth to (a baby) for him so that after old age and my son has separated (beside) suddenly he hired me. O Allah, I complain to you'. The woman continued to say these words until Jibril came down and brought verses regarding the incident.
As in the hadith, this discussion occurred at the time of the Prophet, there is a wife named Khaulah bint Tśa'labah, Khaulah is the wife of 'Aus bin Tsāmit who has done zihār to his wife. In this story, Khaulah is old and cannot get pregnant and have children. Therefore, 'Aus bin Ts̉āmit did zihār deeds to Khaulah. Then Khaulah asked about this to the Prophet, but the Prophet replied that her husband was forbidden to have intercourse with Khaulah forever. Hearing the explanation from the Prophet, Khaulah finally felt sad, because his children were very small (Ash-Shabuni, 2016: 573).

From the above hadith, it is the reason for the descent of the first verse of surah al-Mujādalah which explains that Allah has accepted and allowed the complaint of a woman who argued against the Prophet regarding the case of her husband who had to have zihär for bidden sex herself by saying, "you are to me like my mother's back it is", that is,. Then, he too complained to Allah what had made him sad and restless. Allah hears the talks, talks and arguments of both of you. Verily Allah, hears every voice and sees everything in its most perfect, complete and optimal form, including the talk and debate between that woman and you. The woman referred to in this verse is Khaulah bint Ts'a'labah, while her husband is' Aus bin Tsāmit, one of Anșhar's friends (Zuhaili, 2014: 386).

From this hadith, he produced several laws: First, canceling the custom ignorance that continued until the beginning of Islam, namely seeing zihār being the as same as talaq. Strictly speaking, your words are the same as my mother's back to the wife is considered 
zihār not divorce. Ahmad, ash-Shafi'i and other scholars, emphasized this. Imam ash-Shafi'i said, if someone zihār while he means divorce, he is still in the position of zihār (Ash-Shiddieqy, 2001: 321). Second, zihār is haram, it cannot be done. Third, kafarah is not always obligatory upon the occurrence of zihār recitation, it is only obligatory with the occurrence. This is according to the opinion of the the majority of scholars (Jumhur Ulama). According to ats-Thaury, with the occurrence of zihār it has become obligatory on kafarah. Ibn Hazm shared this opinion from ats-Tśaury and Utsman al-Bitty (Ash-Shiddieqy, 2001:323).

\section{THE FORM OF LAFADZ ZIHĀR}

Lafadz zihār can be divided into two major parts, namely zihār șharih and kinayyah. Both have the same meaning, which is to equate his wife with his mother, but their goals are very different. The explanation is as follows:

\section{Zihār Șharīh}

Zihār Sharih is like saying:



That is,"you are to me like the shoulders of my mother"

So as phrase:



That is, "you are to me like my mother's stomach / head/genitals"

Also like the phrase:

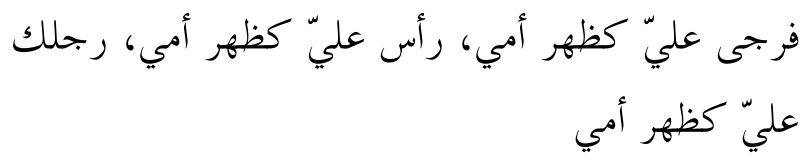

That is, "your genitals or your head or your back or your feet are to me like my mother's shoulders" (al-Barudi, 2010: 506).

Zihār can apply in several circumstances, first, if musyabbah bihi is a limb which is an istimta' place and is not occasionally used for glorifying the wife, such as faraj, back, and so on. Second, if the musyabbah bihi consists of members of the body that are glorified like the spirit and the head, but the form of support is like the husband said: "your faraj is like my mother's head". Third, if sighah zihār which contains musyabbah bihi as above is pronounced in words, it is the same spontaneously or read or written and without coercion. Fourth, if sighah zihār that contains musyabbah bihi as above is expressed in sign language by a mute person who can be understood by many people that he describes the meaning of zihār (Al-Muhami, 1976: 45).

\section{Zihār Kināyah}

Zihār Kināyah is like انت عليّ كأمي , atau انت عليّ مثل أمي (you are like my mother), so here intention counts. If the husband wants his words to be zihār, but if the husband does not want them to be zihār then those words are not zihār. He is not considered a muzahir or person who performs zihār (Zuhaili, 2014: 396).

If he says, "you are to me 'haram' or like my mother's back," then that is zihār and does not enter as divorce. Because the words "you are haram on me" (without the likeness of the back) means haram with divorce. Thus, he is disrespectful, and at 
the same time bears the likeness of zihār. So if he says openly with him, then he is included as an interpretation of one of the possibilities, such an interpretation will be taken (al-Barudi, 2010: 506).

Both of these forms have similarities, namely equalizing his wife with his mother by saying انت علي” كظهر أمي , but the two are clearly different, the difference is in the intention. In the first form, the husband says zihār on purpose and wants to intend to zihār his wife (Zuhaili, 2014: 395). Zihār Kinayah can apply in several situations, such as:

First, if the musyabbah bihi is a member that can be equated to glorify someone such as face, head, spirit, etc. Following the uruf in a place. Second, if the sighah zihār is in the form of writing like that written by a husband who can speak or a husband who is mute but can speak sign language as long as he is not read. Third, if sighah zihār is in the form of sign language for a mute person, but not all mute people can understand that person in general, even only certain experts can understand (al-Muhami, 1976: 45).

Lafaz zihär kinayah is according to the husband's intention. If the husband intends to do zihār, then he applies the $z i h \bar{a} r$. If the husband intends to glorify his wife or does not intend for not anything then applies zihār. If the husband intends to divorce for lafaz kināyah, then divorce will fall. Although it is like that if lafaz sarih or kināyah are only mentioned in the heart, then it does not apply to zihār

\section{Zihār Ta'liq}

Zihār Ta'liq is a regular form that is carried out without being linked to other matters that will happen immediately in cash or tanjiz. It acts without stern anymore, namely as soon as the husband recites it in essence or kinayah. Even so, zihar can also be done in the toughest or ta'liq where unauthorized downloading ta'liq right talaq with something conditions, nature or period. If the conditions, characteristics or period specified in the lafaz apply, then zihār applies.

There are many kinds of zihär ta'liq, first, zihār ta'liq with conditions, for example, zihär ta'liq with conditions is like the husband said to his wife, "if you leave this house, then you are like my mother's back". In these circumstances, zihār will take effect after the wife leaves the house as required by the husband (al-Muhami, 1976: 47). Second, zihār ta'liq with characteristics, for example zihār ta'liq with characteristics is like the husband said to his wife, "if this lamp is red, then you are like my mother's back". In this situation, zihār will occur if it turns out that the nature of the lamp intended by the husband changes to red. Third, zihàr ta'liq with time, for example zihār ta'liq comes with time is like lafaz "when the morning tomorrow, then you are like my mother's back". In this case, the wife will be zihàr when it is morning the next day as intended by the husband.

The conditions for zihār that are practiced are the same as the sharia in ta'liq talaq, obviously, zihār ta'liq will apply if it meets several conditions, namely (al-Muhami, 1976: 47): a) Let the conditions in ta'liq cannot apply, if it has been applied then will apply zihār automatically. b) Let it not be an impossible matter. If it were impossible then there would be no zihār. c) Let zihar ta'liq made when will the marriage still exist, although still within the prescribed 
period talaq raj'i, unauthorized zihar ta'liq made before the marriage or after divorce talaq ba'in because there is no longer binding when the wife when the husband. d) Let the cases in the ta' liq happen within the time of the marriage bond. If the requirements are zihar, ta'liq happens after the wedding has finished with talak $b a^{\prime}$ in it is not zihar valid, because when it is no longer a conjugal relationship and does not meet zihar pillars.

\section{Zihār Muwaqqat}

Zihār habitualis eternal so that it ends with talaq or kaffarat, even though zihār is lafaz sharih, kinayah, tanjiz or ta'liq. However, zihār still exists on a temporary basis. Performing zihār temporarily is legal, but the husband is still sinful even though it is done in a very short time. Laws zihār such will end by themselves, over time. Zihār Muwaqqat is divided into two, namely: first, zihār muwaqqat (temporary) which has a time limit. The validity zihār of which is made against the wife for a short time is because of zihär the conditional. Examples of lafaz like "you are to me like my mother's back for a month". With this lafaz, then zihär applies to the wife within a month from the pronunciation of the lafaz. When the month-long time limit is over, the ending $z i h \bar{a} r$ and the wife will return to the lawful intercourse as before the enactment of $z i h \bar{a}$. Even so, the husband still sins because doing zihâr is haram even though he does it for a short time. If zihār temporary is performed for a time limit exceeding 4 months it is likened to the law of ila'. However, husbands do not use kaffarat ila' if he has intercourse with his wife before the time limit is over, because there is no vow of $i l a^{\prime}$, he is only subject to $z i h \bar{r}$.

Second, Zihār Muwaqqat takes (temporary) which place. Zihār Muwaqqat is specified to apply in certain places only. Zihär muwaqqat is associated with a place. Examples of the pronunciation like: "You are like my mother's back when you are at my grandmother's house." In this case, zihâr only applies as long as the wife is at the husband's grandmother's house. On the other hand, there is no zihār if the wife is somewhere else. Even the husband is lawful to interfere with his wife. Because zihâr only applies if the wife is in the house of the intended grandmother. In terms of time, lafaz zihār like this, can apply without any time limit, but in terms of place it is only limited to places that are $z i h \bar{a} r$.

\section{ZIHĀR IN ULAMA'S IKHTILAF}

The form of a husband's jokes and jokes towards his wife is not completely free without limits. Like a husband jokes in praising his wife who happens to have physical similarities with his mother, so that words come out to his wife to praise him by saying, "your body is like my mother's body", or "your back is like my mother's back". Its purpose is to compliment his wife's beautiful body or back who coincidentally resembles his mother. These words of praise for some scholars are like a coin that has two inseparable sides. On the one hand, it is considered as a form of praise from the husband to his wife, but on the other hand, if he refers to the previous scholars as written in the classical books, he is categorized as zihār (Zuhaili, 1984: 585). 
In the era of ignorance, this was a way to divorce a wife. By likening it to his mother's back, it is as if he is saying, if I interfere with my wife then I interfere with my mother. Previous scholars defined zihār as an expression of a husband equating one part of his wife's body with a woman who is forbidden to marry, such as a biological mother (Zuhaili, 1984: 585). This definition is still circulating in the classical books of previous scholars and no contemporary books have tried to offer a new definition without the moral value of law scholarlyneglecting zihār. If likening the wife to one of the members of the glory as she said, "you are by my side like the eyes of my mother" or "you are like the spirit of my mother", if she intends zihär then that is $z i h \bar{a} r$, but if it is meant only as an honor, then it is not said zihār (Hasan, 2006: 578).

Quraish Shihab in the interpretation of al-Misbah book states that if the husband equates the eyes or head, it is not the body part that becomes the object of sexual relations or the object of sexual relations but in the form of figurative speech it can be said in the context of respect (Hasan, 2006: 472). Abu Bakr in his Tafsir Ahkam book, as the opinion of the Hanafi school of thought, said that if his wife is likened to a visible limb of his mother then it is not called zihār, as he said, "on my side you are like a mother's stomach". This problem is explained at length in the Fiqh book (Hasan, 2006: 579).

In various existing rhetoric, the concept of zihār should be reinterpreted to bridge the problems that occur today. Ibrahim Husain revealed that Islamic law that cannot be grounded (accepted by the general public) is due to maintaining the textual meaning that exists in the classical books of the previous scholars, and these books will become utopian which is only contained in holy texts as documents that not meaningful (Husain, 1997: 101). This means that the concept of zihār in classical books is definitively unable to answer current cases.

According to Abu Zahrah, the stipulation of zihàr is to prevent wrongdoing (Zahrah, t.th: 342). In the present context, the assertion of zihār is lost due to maintaining the concept of zihàr that exists in classical books and its application is enforced in present cases. This is the reason for the importance of reviewing the concept of zihär. In fact, the concept of zihār should ideally bring benefits to husband and wife couples, not to bring harm to husband and wife couples because of the imposition of differences in scope, purpose and purpose.

\section{CONTEXTUAL ZIHĀR IN CONTEMPORARY ERA}

In contemporary times, many couples are married but do not know about the zihār. Even though zihar is a sin that can forbid the relationship between husband and wife. As a result of their ignorance of zihār, they can do zihār without knowing it. That is why currently it is also necessary for husband and wife to know the concept of zihār if it is contextualized in the contemporary era.

Zihār which often occurs in contemporary times is not actually done as a form of speech by the husband to equate his wife with his mahram, but basically husbands today do zihār, there is no deliberate element of doing zihār, because the zihār that is done by the 
husband is a parable or equation for declaring beauty, beauty or the like, not to insult the wife (Ningrum, 2018: 54).

When we compare the era of ignorance with the contemporary era today, in terms of context it is very different. In the era of ignorance, the context was as an insult to the wife, because she could not serve her husband, which caused anger and eventually led to words zihār. Whereas contemporary today, the context is a respect which equates the beauty of another person with his wife which might make the wife hurt by the words of the husband who said it figuratively, and ultimately lead to the words zihār.

Judging from the above comparison, zihār in the jahiliyah era with zihār in the contemporary period was very different because the aims and objectives were also different, although in the end it was interpreted as zihâr. The difference is that $z i h \bar{a} r$ in the era of jahiliyah used straightforward and decisive language to explain its aims and objectives, whereas in contemporary times it uses figurative language without expressing clear intent and purpose.

The Prophet Muhammad taught us that in associating between husband and wife must be careful, not to exceed the limit that can impose zihār. Do not speak words that are ambiguous or unclear so that it becomes a question of the intent and purpose of the conversation. Even though the husband in associating with his wife uses sign language or satirical language, the husband must explain his meaning, even though the husband does not intend to do zihār (Munandar \& Djuned, 2018).
As in the Qur'an has been emphasized by Allah in the surah alAhzab verse 32:

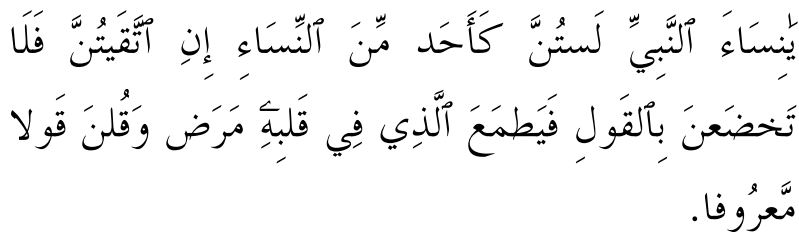

Means: "O Prophet's wives, you people are not like other women, if you are righteous. So don't be submissive in speaking, so that those who have a disease in their hearts desire and speak good words".

In surah al-Ahzāb verse 32 above instructs us to keep our word in all things, because sometimes problems arise due to unfavorable speech. Therefore, a husband and wife must guard their words well in socializing or joking (Kusmidi, 2016).

From the above verse, it can also be learned that how to avoid speech so that it does not belong to zihār, a husband and wife must guard their words well, and treat their partners fairly, because by saying and treating well, it will minimize anger that can cause quarrel. It is from the quarrel that usually the words that come out cannot be controlled, resulting in the fall of words zihār (Hidayah, 2016).

In order to avoid zihār not only happening in contemporary times, husband and wife must understand the following matters: first, in communicating with the wife as much as possible the husband organizes the speech and choice of words when conveying his intentions and wishes. Second, in communicating with the wife, the husband should not raise ambiguous or unclear statements that raise questions about the purpose and purpose of the conversation. Third, in communicating with the wife, the husband should not use a choice of words that lead to statements zihār so that he will 
indirectly be subject to law zihār. Fourth, The choice of words in communication with the wife, even if using sign language or usual, should the husband not lead to statements zihār even though the husband intends to do zihār. Fifth, Husband and wife are recommended by the prophet to joke occasionally but joking must have a limit so as not to exceed the limit that will be a word that could be categorized as zihār.

From the five values above, teach husband and wife or anyone to be careful when communicating, because it could be a problem or even actions zihär take place at the time of communication.

\section{CONCLUSION}

The concept of zihàr according to the Qur'an is zihär before the revelation of the verse in surah al-Mujādalah, the zihār is divorce, in which husband and wife can't be reunited forever, therefore there is prohibition of zihâr after coming to Islam and the revelation, so that women can be protected and feel calm in living life. So that zihār will not be repeated by those who follow after the zihār event exists. Because actually zihār is a lying act.

The contextualization of zihār is to minimize the understanding that is lacking by Muslims in this contemporary era about the discussion of zihār, which many people do not know the truth about zihār itself.

Basically, zihār is an expression that wife and mother are the same, but wife and mother are women who should be equally respected. In addition, it is not allowed to equalize the wife and mother for any reason. In this contemporary context, it is necessary to speak good words in communicating with anyone, especially husbands against wives, so that they are not trapped in words that lead to zihār.

\section{BIBLIOGRAPHY}

Abud, A. G. (1995). Keluarga Muslim Dari Berbagai Masalahnya, Terj. Mudzakkir. Bandung: Pustaka.

Admisi. (1984). Ilmu Fiqih Jilid II. Jakarta: IAIN.

Ash-Shabuni, M. A. (2016). Tafsir AyatAyat Ahkam. Depok: Keira Publishing.

Az-Zuhaili. W. (1984). Figh Al-Islam Wa Adillatuhu. Bairut: Dar al-Fikr.

Az-Zuhaili. W. (2014). Tafsir Al-Munir. Jakarta: Gema Insani.

Barudi, S. I. Z. (2010). Tafsir Wanita. Jakarta: Pustaka al-Kautsar.

Chozin, F. H. (1997). Cara Mudah Menulis Karya Ilmiyah. T.tp: Alpha.

Ghofur, A. (2001). Fikih Keluarga. Jakarta: Pustaka Al-Kautsar.

Hasan, S. A. H. (2006). Tafsir Al-Ahkam. Jakarta: Kencana.

Hidayah, N. (2016). Analisis Hukum Islam Terhadap Persepsi Panggilan Ummi Kepada Istri Sebagai Zihar dalam Kajian Situs Media Sosial. Skripsi. Universitas Islam Negeri Sunan Ampel.

Husain, I. Jenis-Jenis Hukuman Dam Hukum Pidana Islam dalam Jamal D. R. et. Al. (Edt). (1997). Wacana Baru Fiqih Sosial. Bandung: Mizan, 1997 
Kusmidi, H. (2016). Konsep zihar dan implikasi hukumnya dalam perspektif hukum Islam. Mizani: Wacana Hukum, Ekonomi dan Keagamaan, 3(2) http://dx.doi.org/10.29300/mzn.v3i 2.1035

Maraghi, A. M. (1993). Al-Tafsir alMaraghi, Juz 28. Semarang: PT Toha Putra.

Moleong, L. J. (2002). Metodologi Penelitian Kualitatif. Bandung: Remaja Rosda Karya.

Muhami, J. K. (1976). Memahami Hukum Zihār dan Ila'. Malaysia: Darul Minhaj.

Munandar, A., \& Djuned, M. (2018). Zihar dalam Tafsir Fi Zhilal al-Qur'an dan Tafsir al-Mishbah". TAFSE: Journal of Qur'anic Studies, 2(1)

Ningrum, A. W. (2018). Zihar dalam Alquran dan Kontekstualisasi dalam Persoalan Komunikasi Suami Istri". Skripsi. Universitas Islam Negeri Sunan Ampel.

Rahman, F. (1994). Islamic Methodology in History. Delhi: Adam Publishers.

Shiddieqy, T. M. H. (2001). Koleksi HadisHadis Hukum 8. Semarang: PT. Pustaka Rizki Putra.

Shihab, M. Q. (2010). Tafsir Al-Misbah. Jakarta: Lentera Hati.

Zahrah, A. (n.d.) Al-Ahwal al-Syakhsiyyah. Beirut: Dar al-Fikr. 